\title{
Distribution and source identification of dissolved sulfate by dual isotopes in waters of the Babu subterranean river basin, SW China
}

\author{
Kun Ren ${ }^{1,2} \cdot$ Xiaodong Pan ${ }^{1,2} \cdot$ Jie Zeng ${ }^{1,2} \cdot$ Youjun Jiao ${ }^{1,2}$
}

Received: 28 December 2016/Published online: 16 March 2017

(C) The Author(s) 2017. This article is an open access publication
However, using $\delta^{34} \mathrm{~S}_{\mathrm{SO}_{4}}$ alone to track the source of $\mathrm{SO}_{4}{ }^{2-}$ in water has two major limitations. The first is that the $\delta^{34} \mathrm{~S}_{\mathrm{SO}_{4}}$ values in precipitation $(<+10 \%)$ are within a range that overlaps those produced by oxidized sulfides $(<+5 \%$ ), causing tremendous difficulties in distinguishing the two. The second limitation is that $\delta^{34} \mathrm{~S}_{\mathrm{SO}_{4}}$ values increase because of reduction by sulfate-reducing bacteria, a characteristic that is indistinguishable from the $\delta^{34} \mathrm{~S}_{\mathrm{SO}_{4}}$ signal caused by gypsum dissolution $(>+15 \%)[11,12]$. However, the oxygen $\left(\delta^{18} \mathrm{O}_{\mathrm{SO}_{4}}\right)$ isotope values of precipitation are relatively high (approximately +12\%o) [13], ranging from -5 to $+4 \%$ in oxidized sulfides [14] and from +14.5 to $+32.5 \%$ in gypsum $[15,16]$. Therefore, combined use of $\delta^{34} \mathrm{~S}_{\mathrm{SO}_{4}}$ and $\delta^{18} \mathrm{O}_{\mathrm{SO}_{4}}$ can overcome the problem of $\delta^{34} \mathrm{~S}_{\mathrm{SO}_{4}}$ overlap from different sources and help identify the source of $\mathrm{SO}_{4}{ }^{2-}$ in water bodies. Hosono et al. [11] analyzed the $\delta^{34} \mathrm{~S}_{\mathrm{SO}_{4}}$ and $\delta^{18} \mathrm{O}_{\mathrm{SO}_{4}}$ compositions of groundwater in Manila, the capital of the Philippines, and they found artificial chemical compounds (such as sulfurcontaining chemical fertilizers and detergents) in shallow groundwater. Li et al. [1] used $\delta^{34} \mathrm{~S}_{\mathrm{SO}_{4}}$ and $\delta^{18} \mathrm{O}_{\mathrm{SO}_{4}}$ to identify the source of $\mathrm{SO}_{4}{ }^{2-}$ in the Jialing River, a tributary of the Yangtze River in China. They revealed that the main source of $\mathrm{SO}_{4}{ }^{2-}$ in the river is acid rain caused by oxidation of sulfides and coal burning during the wet season, while domestic sewage and industrial wastewater contribute more significantly to the $\mathrm{SO}_{4}{ }^{2-}$ content during the dry season. Using both $\delta^{34} \mathrm{~S}_{\mathrm{SO}_{4}}$ and $\delta^{18} \mathrm{O}_{\mathrm{SO}_{4}}$, Zhang et al. [12] found that $\mathrm{SO}_{4}{ }^{2-}$ in the Yellow River (China) and its tributaries originates from dissolved evaporite minerals and soil sulfates, with additional $\mathrm{SO}_{4}{ }^{2-}$ input by human activities. Marques et al. [2] combined $\delta^{34} \mathrm{~S}_{\mathrm{SO}_{4}}$ and $\delta{ }^{18} \mathrm{O}_{\mathrm{SO}_{4}}$ to identify the source of $\mathrm{SO}_{4}{ }^{2-}$ in groundwater. They found 
that $\mathrm{SO}_{4}{ }^{2-}$ in groundwater in the Caldas da Rainha area in Portugal originated mainly from dissolved gypsum and anhydrite. Using the same approach, Al-Charideh et al. [17] identified gypsum dissolution as the main source of $\mathrm{SO}_{4}{ }^{2-}$ in a deep karst aquifer in the Aleppo Basin in northern Syria.

Groundwater in karst areas is an important water resource. Approximately $20-25 \%$ of the world's population use groundwater from karst areas as drinking water [18]. However, pollutants can penetrate into underground aquifers directly or indirectly through thin soil layers, sinkholes, karst windows, and karst fissures. In addition, the poor self-purification ability of aquifers in karst areas makes groundwater in such areas vulnerable to pollution and difficult to restore once polluted [19-21]. Therefore, it is very important to identify accurately the source of pollutants in surface water and groundwater in karst areas. A hydrogeological and geo-environmental survey conducted in Guizhou Province of southwestern China in 2012 revealed that the $\mathrm{SO}_{4}{ }^{2-}$ concentration in the Babu subterranean river basin (BSRB) (surface water and groundwater) was $>50 \mathrm{mg} \mathrm{L}^{-1}$ with a peak of up to $1959.8 \mathrm{mg} \mathrm{L}^{-1}$, significantly exceeding the drinking water standards in China $\left(250 \mathrm{mg} \mathrm{L}^{-1}\right)$. Nevertheless, groundwater remains the principal source of drinking water for residents in this area; in particular, it is the only source of drinking water during the dry season. Long-term consumption of water with such a high $\mathrm{SO}_{4}{ }^{2-}$ content inevitably endangers human health, causing illnesses such as diarrhea, dehydration, and gastrointestinal disorders.

This study focused on the BSRB in SW China. It examined the surface water and groundwater as carriers and analyzed $\delta^{34} \mathrm{~S}_{\mathrm{SO}_{4}}$ and $\delta^{18} \mathrm{O}_{\mathrm{SO}_{4}}$ to accomplish a number of objectives: (1) to find the distribution characteristics of $\mathrm{SO}_{4}{ }^{2-}$ in rainwater, surface water, and groundwater; (2) to identify the sources of $\mathrm{SO}_{4}{ }^{2-}$ in surface water and groundwater; and (3) to elucidate the contributions of different sources to the $\mathrm{SO}_{4}{ }^{2-}$ content of the Babu subterranean river. The aims of this study were to provide reference scientific data to enable the development of an effective strategy for the reduction of inputs of $\mathrm{SO}_{4}{ }^{2-}$ from different sources, and to find an appropriate balance between economic development and the preservation of water quality in karst areas.

\section{Overview of the study area}

The BSRB in the northeast of the Yunnan Guizhou Plateau covers an area of $18.08 \mathrm{~km}^{2}$. It is located between the north-south-trending tectonic zone of Sichuan and Guizhou and the north-south-trending tectonic zone of western
Yunnan. The area has a mid-subtropical monsoon climate with a multiyear average annual temperature of $14.1{ }^{\circ} \mathrm{C}$. The average annual precipitation is $1402.8 \mathrm{~mm}, 83.6 \%$ of which is concentrated mainly between May and October. The strata in this area are characterized by shallow-marine sediments of mostly Permian and Triassic age (Fig. 1), with a relatively thin Quaternary upper layer. The Permian and Triassic strata cover 1.17 and $16.91 \mathrm{~km}^{2}$, accounting for 6.47 and $93.53 \%$ of the total area, respectively. The Quaternary deposits consist of clay, loam, and gravel and they cover the bedrock. Figure 2 shows the lithological information obtained from five boreholes. The carbonate aquifer group is distributed most widely, covering an area of $14.96 \mathrm{~km}^{2}$, which accounts for $82.7 \%$ of the total area. The clastic aquifer group occupies only $3.12 \mathrm{~km}^{2}$, accounting for $17.3 \%$ of the total area. The studied basin is a bare karst area where carbonates provide the necessary physical conditions for karst development and where sinkholes, karst windows, and karst caves have developed. The subterranean river investigated in the present study is located upstream of the Wujiang River and it belongs to the Yangtze River system. It runs from southeast to northwest into the Dina River.

The BSRB belongs to the administrative district of Zhijin County in Guizhou Province. The area has a thin and barren soil layer, fragile ecological environment, and it is sparsely populated with only 10-20 resident households. Crops planted within the area comprise mainly rice and corn; however, in order to reduce costs, farmers rarely use fertilizers because of the frequent occurrence of both floods and droughts. There is no industrial activity within the study area except for a few coal mines.

\section{Sampling and analysis}

Given the small area of the BSRS, ten representative water samples were collected in August 2014 with consideration of the water sources, recharge area, and lithology of the outcrops at the sampling sites. The samples included one rainwater sample (RW), three surface water samples (SW), and six groundwater samples $(\mathrm{GW})$. The distribution of the sampling sites is shown in Fig. 1.

\section{Sampling}

Water samples for conventional hydrochemical analyses of ions, $\delta \mathrm{D}_{\mathrm{H}_{2} \mathrm{O}}$, and $\delta^{18} \mathrm{O}_{\mathrm{H}_{2} \mathrm{O}}$ were collected using $50-\mathrm{mL}$ polyethylene bottles. For cation analysis, super pure $\mathrm{HNO}_{3}$ (1:1) was added to the samples until a $\mathrm{pH}$ value of $<2$ was attained. For analyses of sulfate $\delta^{34} \mathrm{~S}_{\mathrm{SO}_{4}}$ and $\delta^{18} \mathrm{O}_{\mathrm{SO}_{4}}$, the samples were collected using 2-L brown plastic bottles and 
a

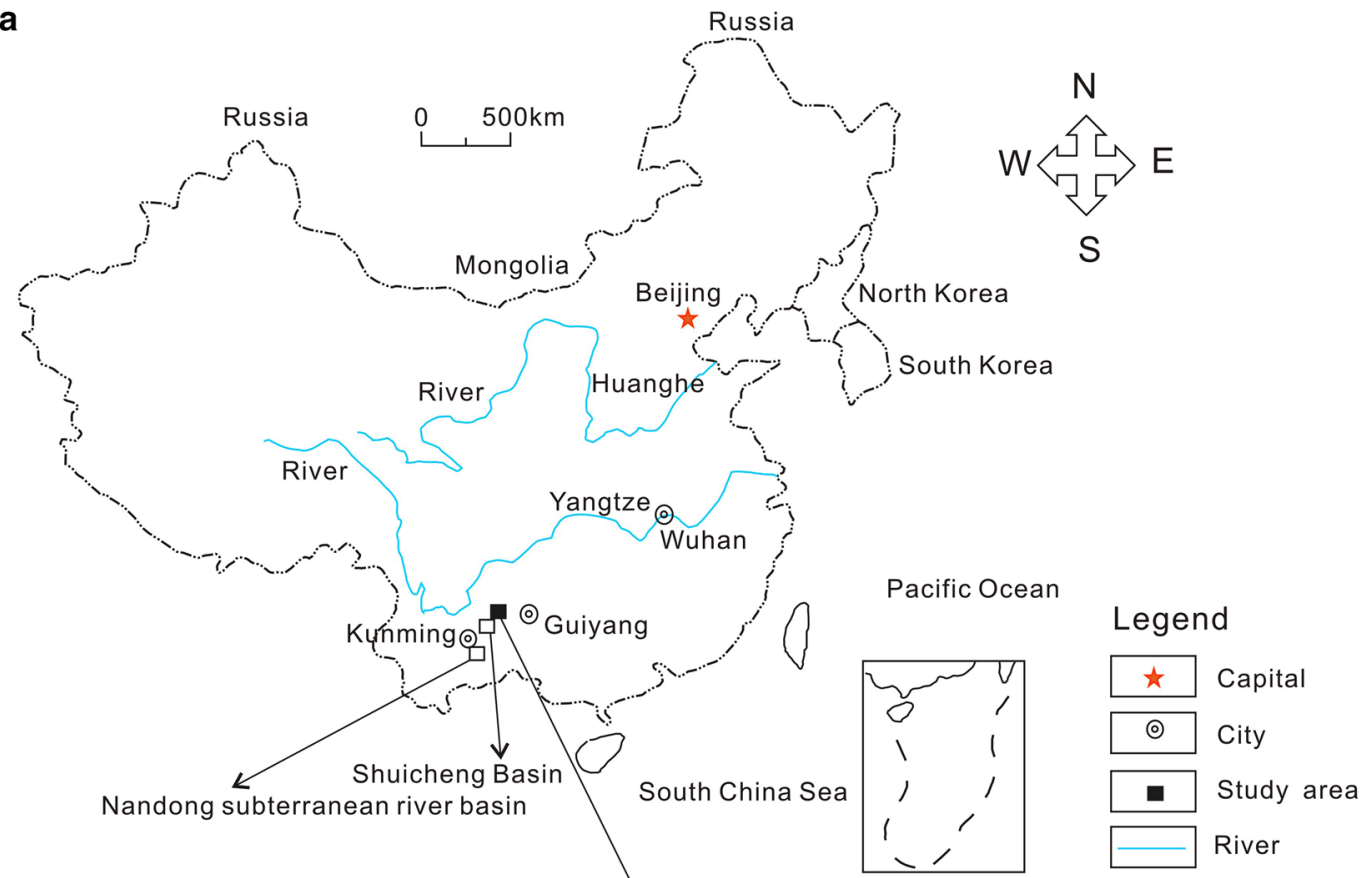

b

Legend

SW01 Sample point number

() Town

0 Village

$\otimes$ Sinkhole

G Gravity-fed spring

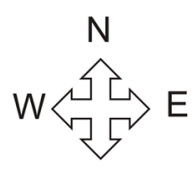

$\mathrm{S}$

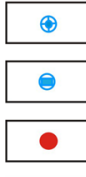

Karst window

- Karst well

Borehole

$\Omega$ Water wave

$\downarrow$ Dirction of groundwater flow

7 Dirction of surface water flow

- Subterranean river
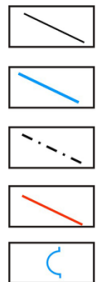

Stratigraphic boundary

Surface river

Study area

Fault

Subterranean river outlet

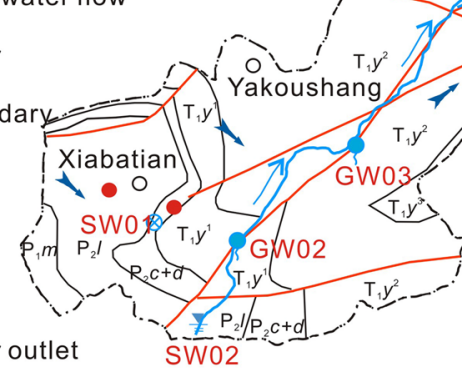

Vanrenfe
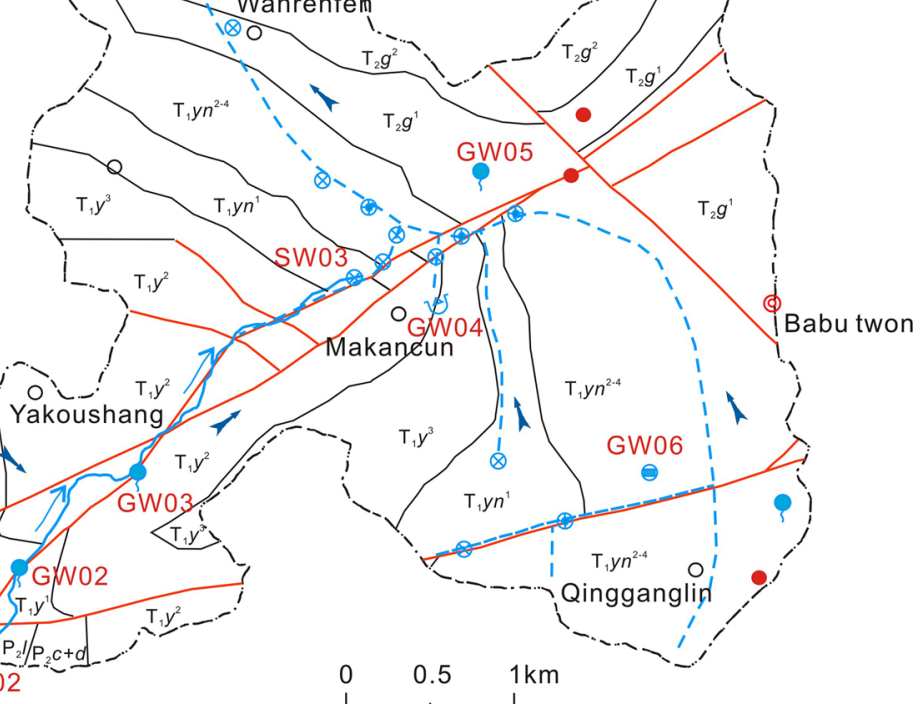

Fig. 1 Location (a) and hydrogeological map and sampling site distribution (b) of the BSRB

super pure $\mathrm{HCl}$ was added to reach a $\mathrm{pH}$ value of $<2$. Subsequently, $\mathrm{BaCl}_{2}$ was added to precipitate all $\mathrm{SO}_{4}{ }^{2-}$ as $\mathrm{BaSO}_{4}$, which was then purified for further analysis using diethylenetriaminepentaacetic acid. After freezing, the obtained $\mathrm{BaSO}_{4}$ powder was sent to China University of Geosciences (Wuhan, China) for isotopic analysis. All 


\begin{tabular}{|c|c|c|c|c|c|}
\hline 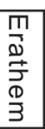 & $\underset{\substack{\infty \\
\frac{\infty}{D} \\
\frac{1}{3}}}{3}$ & \multicolumn{2}{|c|}{ Formation } & $\begin{array}{l}\text { Stratig- } \\
\text { raphic } \\
\text { column }\end{array}$ & $\begin{array}{l}\text { Petrographic } \\
\text { descripition }\end{array}$ \\
\hline 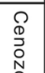 & 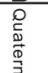 & \multicolumn{2}{|c|}{ Q } & in & clay, loam, and gravel \\
\hline \multirow{10}{*}{ 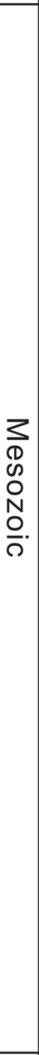 } & \multirow{10}{*}{ 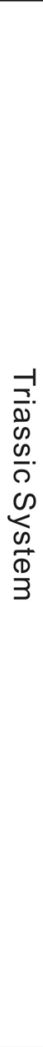 } & \multirow{3}{*}{ 只 } & $\mathrm{T}_{2} g^{3}$ & 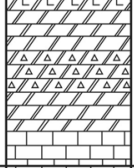 & $\begin{array}{l}\text { dolomite, } \\
\text { calcite dolimite, } \\
\text { carneule, } \\
\text { limestone }\end{array}$ \\
\hline & & & $\mathrm{T}_{2} g^{2}$ & 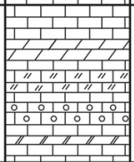 & $\begin{array}{l}\text { limestone, } \\
\text { marlite, } \\
\text { dolomitic limestone, } \\
\text { oolitic limestone }\end{array}$ \\
\hline & & & $\mathrm{T}_{2} g^{1}$ & 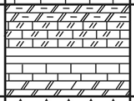 & $\rightarrow g$ \\
\hline & & \multirow{4}{*}{ 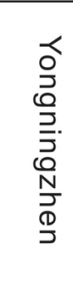 } & $\mathrm{T}_{1} y n^{4}$ & 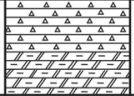 & $\begin{array}{l}\text { breccia, } \\
\text { argillaceous dolomite }\end{array}$ \\
\hline & & & $\mathrm{T}_{1} y n^{3}$ & & limestone \\
\hline & & & $\mathrm{T}_{1} y n^{2}$ & & mudstone \\
\hline & & & $\mathrm{T}_{1} y n^{1}$ & 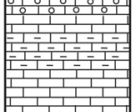 & $\begin{array}{l}\text { limestone, } \\
\text { oolitic limestone, } \\
\text { argillaceous limestone }\end{array}$ \\
\hline & & \multirow{3}{*}{ 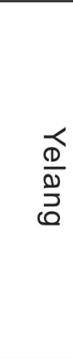 } & $\mathrm{T}_{1} y^{3}$ & 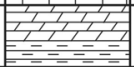 & marlite, mudstone \\
\hline & & & $\mathrm{T}_{1} y^{2}$ & 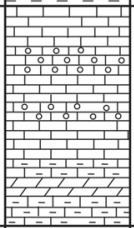 & $\begin{array}{l}\text { limestone, } \\
\text { oolitic limestone, } \\
\text { argillaceous limestone, } \\
\text { marlite }\end{array}$ \\
\hline & & & $\mathrm{T}_{1} y^{1}$ & -1 & $\begin{array}{l}\text { silty mudstone, } \\
\text { siltstone }\end{array}$ \\
\hline \multirow{5}{*}{$\begin{array}{l}D \\
\frac{D}{D} \\
D \\
N \\
\text { O. } \\
\frac{0}{0}\end{array}$} & \multirow{5}{*}{ 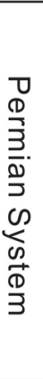 } & \multicolumn{2}{|c|}{ Dalong $\mathrm{P}_{2} \mathrm{~d}$} & & $\Delta$ coal seam \\
\hline & & \multicolumn{2}{|c|}{ Changxing $\mathrm{P}_{2} \mathrm{C}$} & $\begin{array}{l}-z \\
-\ldots \\
\cdots\end{array}$ & $\longrightarrow$ coal seam \\
\hline & & \multirow{2}{*}{$\begin{array}{l}\text { 둥 } \\
\frac{0}{2} \\
\frac{0}{0} \\
\frac{1}{2}\end{array}$} & $\mathrm{P}_{2} I^{2}$ & $\because$ & \multirow[t]{2}{*}{$\rightarrow$ coal seam } \\
\hline & & & $\mathrm{P}_{2} I^{1}$ & 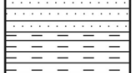 & \\
\hline & & 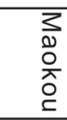 & $\mathrm{P}_{1} m^{2}$ & 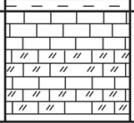 & $\begin{array}{l}\text { limestone, } \\
\text { dolomitic limestone }\end{array}$ \\
\hline
\end{tabular}

Fig. 2 Stratigraphic column of the BSRB

water samples were filtered through a membrane filter $\left(0.45-\mu \mathrm{m}\right.$ pore size) prior to collection and stored at $4{ }^{\circ} \mathrm{C}$ until analysis.

\section{Sample analysis}

$\mathrm{HCO}_{3}{ }^{-}$was titrated in the field using an alkalimeter with precision of $0.1 \mathrm{mmol} \mathrm{L}^{-1}$. The $\mathrm{pH}$ value of the water was determined in the field using a WTW Multi3430 (WTW Company, Germany) with precision of 0.01. Cations $\left(\mathrm{Ca}^{2+}\right.$, $\mathrm{Mg}^{2+}, \mathrm{Na}^{+}$, and $\mathrm{K}^{+}$) were analyzed by atomic absorption spectrometry and anions $\left(\mathrm{SO}_{4}{ }^{2-}, \mathrm{Cl}^{-}\right.$, and $\left.\mathrm{NO}_{3}{ }^{-}\right)$were measured by high-performance liquid chromatography. Both $\delta \mathrm{D}_{\mathrm{H}_{2} \mathrm{O}}$ and $\delta^{18} \mathrm{O}_{\mathrm{H}_{2} \mathrm{O}}$ compositions were determined using a stable isotope mass spectrometer (MAT253, Thermo Fisher Scientific, USA) with precision greater than 0.1 and $0.05 \%$, respectively. The $\delta^{34} \mathrm{~S}_{\mathrm{SO}_{4}}$ and $\delta^{18} \mathrm{O}_{\mathrm{SO}_{4}}$ compositions were analyzed using an elemental analyzer (Carlo Erba 1108) combined with a stable isotope mass spectrometer (Delta V Advantage and MAT253) with precision greater than 0.2 and $0.05 \%$, respectively. Anions $\left(\mathrm{SO}_{4}{ }^{2-}, \mathrm{Cl}^{-}\right.$, and $\left.\mathrm{NO}_{3}{ }^{-}\right)$, cations $\left(\mathrm{Ca}^{2+}, \mathrm{Mg}^{2+}, \mathrm{Na}^{+}\right.$, and $\mathrm{K}^{+}$), and $\delta \mathrm{D}_{\mathrm{H}_{2} \mathrm{O}}$ and $\delta^{18} \mathrm{O}_{\mathrm{H}_{2} \mathrm{O}}$ compositions were analyzed at the Karst Geological Resources and Environment Supervision and Monitoring Center of the Ministry of Land and Resources.

\section{Results}

\section{Hydrochemical characteristics}

Table 1 shows the chemical compositions of rainwater, surface water, and groundwater in the BSRB. The level of total dissolved solids ranges from 352.88 to $933.19 \mathrm{mg} \mathrm{L}^{-1}$ (average: $588.49 \mathrm{mg} \mathrm{L}^{-1}$ ) in surface water and from 259.36 to $387.86 \mathrm{mg} \mathrm{L}^{-1}$ (average: $332.31 \mathrm{mg} \mathrm{L}^{-1}$ ) in groundwater. The rainwater has a $\mathrm{pH}$ value of 6.85 , indicating that it is slightly acidic and belongs to the hydrochemical water type of $\mathrm{SO}_{4} \cdot \mathrm{HCO}_{3}-\mathrm{Ca}$. Among the three surface water samples, SW01 has the lowest $\mathrm{pH}(2.70)$ and its $\mathrm{SO}_{4}{ }^{2-}$ concentration is as high as $705.79 \mathrm{mg} \mathrm{L}^{-1}$. However, it does not reach a detectable level of $\mathrm{HCO}_{3}{ }^{-}$and thus, it belongs to the hydrochemical water type of $\mathrm{SO}_{4}-\mathrm{Ca} \cdot \mathrm{Mg}$. Samples SW02 and $\mathrm{SW} 03$ have a pH value of 7.23 and 7.69, respectively. In these two samples, $\mathrm{Ca}^{2+}$ is the dominant cation $(>75 \%$ in terms of milligram equivalent per liter $\left(\mathrm{meq}^{-1}\right)$ ) and $\left[\mathrm{HCO}_{3}{ }^{-}+\mathrm{SO}_{4}{ }^{2-}\right]$ are the dominant anions, but the proportion of $\left[\mathrm{SO}_{4}{ }^{2-}\right]$ is higher than that of $\left[\mathrm{HCO}_{3}{ }^{-}\right]$. Therefore, the hydrochemical type of SW02 and SW03 is $\mathrm{SO}_{4} \cdot \mathrm{HCO}_{3}-$ $\mathrm{Ca}$. The groundwater samples have $\mathrm{pH}$ values between 6.60 and 7.70 (average: 7.35 ); thus, they are considered slightly alkaline. In the groundwater samples, $\left[\mathrm{Ca}^{2+}+\mathrm{Mg}^{2+}\right]$ are the most dominant cations, accounting for $>90 \%$ of the positive charges, while $\left[\mathrm{K}^{+}\right]$and $\left[\mathrm{Na}^{+}\right]$together account for $<10 \%$. $\left[\mathrm{HCO}_{3}{ }^{-}+\mathrm{SO}_{4}{ }^{2-}\right]$ are the dominant anions $(>95 \%)$. In samples GW01 and GW04, the $\left[\mathrm{HCO}_{3}{ }^{-}\right]$concentrations are higher than those of $\left[\mathrm{SO}_{4}{ }^{2-}\right]$ and their hydrochemical water type is $\mathrm{HCO}_{3} \cdot \mathrm{SO}_{4}-\mathrm{Ca}$. In samples GW02 and GW03, the $\left[\mathrm{SO}_{4}{ }^{2-}\right]$ concentrations are higher than the $\left[\mathrm{HCO}_{3}{ }^{-}\right]$concentrations. $\left[\mathrm{Cl}^{-}\right]$accounts for $<5 \%$ and their hydrochemical water type is $\mathrm{SO}_{4} \cdot \mathrm{HCO}_{3}-\mathrm{Ca}$. In GW05 and GW06, $\mathrm{SO}_{4}{ }^{2-}$ accounts for $<20 \%$ of the total 
Table 1 Basic hydrochemical characteristics of rainwater, surface water, and groundwater in the BSRB

\begin{tabular}{|c|c|c|c|c|c|c|c|c|c|c|c|}
\hline $\begin{array}{l}\text { Sample } \\
\text { ID }\end{array}$ & $\mathrm{pH}$ & $\begin{array}{l}\text { TDS } \\
\mathrm{mg} \mathrm{L}^{-1}\end{array}$ & $\mathrm{~K}^{+}$ & $\mathrm{Na}^{+}$ & $\mathrm{Ca}^{2+}$ & $\mathrm{Mg}^{2+}$ & $\mathrm{SO}_{4}{ }^{2-}$ & $\mathrm{HCO}_{3}{ }^{-}$ & $\mathrm{Cl}^{-}$ & $\mathrm{NO}_{3}{ }^{-}$ & $\begin{array}{l}\text { Outcropping } \\
\text { stratum }\end{array}$ \\
\hline \multicolumn{12}{|c|}{ Rain-water } \\
\hline RW & 6.85 & - & 0.09 & 0.38 & 6.98 & 0.24 & 12.36 & 9.31 & 1.38 & $-{ }^{\mathrm{a}}$ & \\
\hline \multicolumn{12}{|c|}{ Surface water } \\
\hline SW01 & 2.70 & 933.19 & 3.97 & 9.45 & 92.14 & 32.80 & 705.79 & 0.00 & 2.79 & 0.94 & $\mathrm{P}_{2} l$ \\
\hline SW02 & 7.23 & 479.41 & 4.36 & 8.06 & 112.00 & 17.65 & 256.15 & 124.04 & 5.08 & 5.81 & $\mathrm{P}_{2} l$ \\
\hline SW03 & 7.69 & 352.88 & 1.83 & 5.17 & 90.76 & 12.53 & 150.10 & 144.71 & 2.76 & 9.88 & $\mathrm{~T}_{1} y n^{1}$ \\
\hline \multicolumn{12}{|c|}{ Groundwater } \\
\hline GW01 & 7.54 & 325.83 & 2.14 & 3.57 & 84.80 & 10.12 & 94.53 & 181.28 & 4.42 & 28.72 & $\mathrm{~T}_{1} y n^{2-4}$ \\
\hline GW02 & 6.60 & 307.16 & 1.38 & 4.44 & 69.87 & 9.75 & 152.78 & 79.51 & 1.46 & 9.57 & $\mathrm{~T}_{1} y^{1}$ \\
\hline GW03 & 7.27 & 353.39 & 1.42 & 4.50 & 93.80 & 9.71 & 136.72 & 154.25 & 3.29 & 18.40 & $\mathrm{~T}_{1} y^{2}$ \\
\hline GW04 & 7.35 & 259.36 & 1.20 & 2.80 & 76.33 & 3.66 & 47.22 & 176.51 & 3.16 & - & $\mathrm{T}_{1} y^{2-3}$ \\
\hline GW05 & 7.70 & 360.26 & 1.91 & 1.70 & 69.68 & 40.22 & 58.33 & 338.71 & 4.27 & 2.00 & $\mathrm{~T}_{2} \mathrm{~g}^{1}$ \\
\hline GW06 & 7.61 & 387.86 & 1.81 & 3.85 & 94.75 & 23.57 & 54.06 & 301.34 & 7.64 & - & $\mathrm{T}_{1} y n^{2-4}$ \\
\hline
\end{tabular}

TDS Total dissolved solids

${ }^{\text {a }}$ No data

negative charges in meq $\mathrm{L}^{-1}$, while $\left[\mathrm{Mg}^{2+}\right]$ accounts for $>20 \%$ of the positive charges, resulting in a hydrochemical water type of $\mathrm{HCO}_{3}-\mathrm{Ca} \cdot \mathrm{Mg}$. The concentrations of $\left[\mathrm{K}^{+}+\mathrm{Na}^{+}\right],\left[\mathrm{Cl}^{-}\right]$and $\left[\mathrm{NO}_{3}{ }^{-}\right]$in rainwater, surface water, and groundwater in the BSRB are low; thus, do not play dominant roles among the cations and anions.

\section{Isotope values}

Table 2 shows the $\delta \mathrm{D}_{\mathrm{H}_{2} \mathrm{O}}$ values of the surface water samples vary between -45.7 and $-32.1 \%$ (average: $-40.47 \%$ ), while the $\delta^{18} \mathrm{O}_{\mathrm{H}_{2} \mathrm{O}}$ values range from -7.19 to $-5.01 \%$ (average: $-6.33 \%$ ). For the groundwater samples, the $\delta \mathrm{D}_{\mathrm{H}_{2} \mathrm{O}}$ values range between -56.2 and $-46.4 \%$ (average: $-52.62 \%$ ), and the $\delta^{18} \mathrm{O}_{\mathrm{H}_{2} \mathrm{O}}$ values vary between -8.45 and $-7.34 \%$ (average: $-8.11 \%$ ).

The $\delta^{34} \mathrm{~S}_{\mathrm{SO}_{4}}$ values of the surface water samples range between -12.98 and $-7.58 \%$ (average: $-10.49 \%$ ), and the $\delta^{18} \mathrm{O}_{\mathrm{SO}_{4}}$ values vary between -0.54 and $+9.13 \%$ (average: $+4.66 \%$ ). For the groundwater samples, the $\delta^{34} \mathrm{~S}_{\mathrm{SO}_{4}}$ values range between -14.32 and $+16.58 \%$ o (average: $-2.87 \%$ ), and the $\delta^{18} \mathrm{O}$ so4 values vary between +2.81 and $+14.35 \%$ (average: $+7.06 \%$ ).

\section{Discussion}

\section{Surface water and groundwater recharge sources}

Because of the rapid transformation between surface water and groundwater in karst areas, it is necessary to understand the local sources that replenish surface water and
Table 2 Isotope values (\%) of surface water and groundwater in the BSRB

\begin{tabular}{lrrrr}
\hline Sample ID & $\delta D_{\mathrm{H}_{2} \mathrm{O}}$ & $\delta^{18} \mathrm{O}_{\mathrm{H}_{2} \mathrm{O}}$ & $\delta^{34} \mathrm{~S}_{\mathrm{SO}_{4}}$ & $\delta^{18} \mathrm{O}_{\mathrm{SO}_{4}}$ \\
\hline Surface water & & & & \\
SW01 & -43.60 & -6.79 & -12.98 & -0.54 \\
SW02 & -32.10 & -5.01 & -7.58 & 9.13 \\
SW03 & -45.70 & -7.19 & -10.91 & 5.40 \\
Groundwater & & & & \\
GW01 & -52.50 & -8.02 & 3.03 & 8.98 \\
GW02 & -51.60 & -8.10 & -14.32 & 2.81 \\
GW03 & -46.40 & -7.34 & -10.49 & 6.02 \\
GW04 & -54.70 & -8.45 & -6.80 & 6.72 \\
GW05 & -56.20 & -8.37 & 16.58 & 14.35 \\
GW06 & -54.30 & -8.40 & -5.19 & 3.48 \\
\hline
\end{tabular}

groundwater in order to explore further the sources of the components in these waters, particularly pollutants. Under low-temperature conditions, $\delta \mathrm{D}_{\mathrm{H}_{2} \mathrm{O}}$ and $\delta^{18} \mathrm{O}_{\mathrm{H}_{2} \mathrm{O}}$ compositions of water do not change through water-rock interactions [22]; thus, they are used widely to identify groundwater or mixed water recharge sources [23-26]. Craig [27] presented an equation for the relationship between $\delta \mathrm{D}_{\mathrm{H}_{2} \mathrm{O}}$ and $\delta{ }^{18} \mathrm{O}_{\mathrm{H}_{2} \mathrm{O}}$, which has become known as the global meteoric water line: $\delta \mathrm{D}_{\mathrm{H}_{2} \mathrm{O}}=8.0 \delta^{18} \mathrm{O}_{\mathrm{H}_{2} \mathrm{O}}+10.0$. Zhao et al. [28] proposed an equation for the relationship between $\delta \mathrm{D}_{\mathrm{H}_{2} \mathrm{O}}$ and $\delta^{18} \mathrm{O}_{\mathrm{H}_{2} \mathrm{O}}$ for southwestern China: $\delta \mathrm{D}_{\mathrm{H}_{2} \mathrm{O}}=7.96{ }^{18} \mathrm{O}_{\mathrm{H}_{2} \mathrm{O}}+9.52$. Figure 3 shows that the $\delta \mathrm{D}_{\mathrm{H}_{2} \mathrm{O}}$ and $\delta^{18} \mathrm{O}_{\mathrm{H}_{2} \mathrm{O}}$ values of the surface water and groundwater samples plot close to the meteoric water line for southwestern China, indicating that the source of 
surface water and groundwater in the BSRB is atmospheric precipitation. Surface runoff or lake water resulting from precipitation is typically affected to a certain extent by evaporation, whereas precipitation that infiltrates directly through sinkholes or penetrates into an underground aquifer through the soil layers is not strongly affected by evaporation. Therefore, the $\delta \mathrm{D}_{\mathrm{H}_{2} \mathrm{O}}$ and $\delta{ }^{18} \mathrm{O}_{\mathrm{H}_{2} \mathrm{O}}$ values of the surface water samples are higher than the groundwater samples (Fig. 3). This is consistent with results reported by both $\mathrm{Pu}$ et al. [20] and Yang et al. [29] from the Lijiang River Basin on the northwestern Yunnan Guizhou plateau and the Qingmuguan subterranean river in the eastern Sichuan Basin, respectively (both located in the karst area of southwestern China).

\section{Contribution of sulfuric acid to dissolution of carbonate rocks}

Karstification occurs in an unbalanced solid-liquid-gas open system and it is a dynamic process involving the $\mathrm{CO}_{2}-\mathrm{H}_{2} \mathrm{O}-\mathrm{Ca}^{2+}$ equilibrium. When only $\mathrm{CO}_{2}$ is involved in the dissolution of carbonate rocks, the following relationship between dissolved cations and $\mathrm{HCO}_{3}{ }^{-}$is observed: $\left[\mathrm{Ca}^{2+}+\mathrm{Mg}^{2+}\right]:\left[\mathrm{HCO}_{3}{ }^{-}\right]=1: 1$. The dissolution reaction can be written as follows:

$$
\begin{aligned}
& \mathrm{Ca}_{x} \mathrm{Mg}_{(1-x)} \mathrm{CO}_{3}+\mathrm{H}_{2} \mathrm{O}+\mathrm{CO}_{2} \\
& \quad=x \mathrm{Ca}^{2+}+(1-x) \mathrm{Mg}^{2+}+2 \mathrm{HCO}_{3}^{-} .
\end{aligned}
$$

The compositional relationship of the dominant cations $\left[\mathrm{Ca}^{2+}+\mathrm{Mg}^{2+}\right]$ and the dominant anion $\left[\mathrm{HCO}_{3}{ }^{-}\right]$in the surface water and groundwater samples from the BSRB deviates from the $\left[\mathrm{Ca}^{2+}+\mathrm{Mg}^{2+}\right]:\left[\mathrm{HCO}_{3}{ }^{-}\right]=1: 1$ equivalence line, with the samples plotting on the right side of the line (Fig. 4a). This indicates that other acids in both the surface water and groundwater are involved in the dissolution of carbonate rocks. Previous research has shown that sulfuric acid derived from natural processes and human

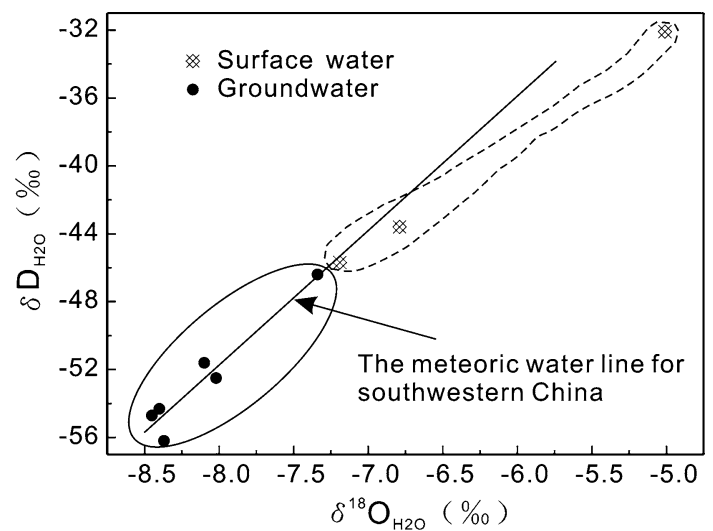

Fig. 3 Relationship between $\delta \mathrm{D}_{\mathrm{H} 2 \mathrm{O}}$ and $\delta^{18} \mathrm{O}_{\mathrm{H} 2 \mathrm{O}}$ values in surface water and groundwater in the BSRB activities can contribute to dissolution of carbonate rocks [30]. When sulfuric acid is present, the dissolution reaction can be written as follows:

$$
\begin{aligned}
& 3 \mathrm{Ca}_{x} \mathrm{Mg}_{(1-x)} \mathrm{CO}_{3}+\mathrm{H}_{2} \mathrm{SO}_{4}+\mathrm{H}_{2} \mathrm{CO}_{3} \\
& \quad=3 x \mathrm{Ca}^{2+}+3(1-x) \mathrm{Mg}^{2+}+\mathrm{SO}_{4}{ }^{2-}+4 \mathrm{HCO}_{3}^{-} .
\end{aligned}
$$

As shown in Eq. (2), when sulfuric and carbonic acid jointly participate in the dissolution of carbonate rocks, the following relationship between dissolved cations and anions is observed: $\left[\mathrm{Ca}^{2+}+\mathrm{Mg}^{2+}\right]:\left[\mathrm{HCO}_{3}{ }^{-}+\mathrm{SO}_{4}{ }^{2-}\right]=1: 1$. The compositional relationship of the dominant cations $\left[\mathrm{Ca}^{2+}+\mathrm{Mg}^{2+}\right]$ and the dominant anions $\left[\mathrm{HCO}_{3}{ }^{-}+\right.$ $\left.\mathrm{SO}_{4}{ }^{2-}\right]$ in the surface water and groundwater samples from the BSRB are both at or close to the $\left[\mathrm{Ca}^{2+}+\mathrm{Mg}^{2+}\right]:[-$ $\left.\mathrm{HCO}_{3}{ }^{-}+\mathrm{SO}_{4}{ }^{2-}\right]=1: 1$ equivalence line (Fig. 4b). This suggests that both sulfuric and carbonic acid participate in the dissolution of carbonate rocks in the BSRB, and that dissolution of carbonate rocks is the main source of $\mathrm{Ca}^{2+}$, $\mathrm{Mg}^{2+}$, and $\mathrm{HCO}_{3}{ }^{-}$in both surface water and groundwater.

$\mathrm{Ca}^{2+}$ and $\mathrm{Mg}^{2+}$ in rainwater are derived mainly from weathering of carbonate rocks and $\mathrm{Ca} / \mathrm{Mg}$-containing particles produced by cement industries [31]. The $\left[\mathrm{Ca}^{2+}+\right.$ $\left.\mathrm{Mg}^{2+}\right]:\left[\mathrm{HCO}_{3}{ }^{-}\right]$values for the rainwater sample also deviate from the $1: 1$ equivalence line, plotting on the right side of the line (Fig. 4a). When $\left[\mathrm{SO}_{4}{ }^{2-}\right]$ is considered, the $\left[\mathrm{Ca}^{2+}+\mathrm{Mg}^{2+}\right]:\left[\mathrm{HCO}_{3}{ }^{-}+\mathrm{SO}_{4}{ }^{2-}\right]$ value lies on the $1: 1$ equivalence line (Fig. $4 \mathrm{~b}$ ), indicating that sulfuric acid participates in the dissolution of $\mathrm{Ca} / \mathrm{Mg}$-containing particles.

\section{$\mathrm{SO}_{4}{ }^{2-}$ concentrations in rainwater, surface water, and groundwater}

Li et al. [9] reported that in the neighboring Shuicheng Basin (Fig. 1), $\mathrm{SO}_{4}{ }^{2-}$ concentrations of $63.1-110 \mathrm{mg} \mathrm{L}^{-1}$ (average: $84.24 \mathrm{mg} \mathrm{L}^{-1}$ ) were measured in surface water samples $(n=5)$. In ground water, the concentrations were $30-61.1 \mathrm{mg} \mathrm{L}^{-1}$, with an average of $45.55 \mathrm{mg} \mathrm{L}^{-1}$ $(n=2)$. For the Nandong subterranean river basin in Yunan Province, Jiang [32] reported concentrations of $\mathrm{SO}_{4}{ }^{2-}$ of $4.0-5.2 \mathrm{mg} \mathrm{L}^{-1}$ (average: $4.5 \mathrm{mg} \mathrm{L}^{-1}$ ) in rainwater $(n=3), 46.8-72.6 \mathrm{mg} \mathrm{L}^{-1}$ (average: $57.66 \mathrm{mg} \mathrm{L}^{-1}$ ) in surface water $(n=7)$, and $1.3-91.4 \mathrm{mg} \mathrm{L}^{-1}$ (average: $\left.32.7 \mathrm{mg} \mathrm{L}^{-1}\right)$ in groundwater $(n=36)$. The BSRB has $\mathrm{SO}_{4}{ }^{2-}$ concentrations of $12.36 \mathrm{mg} \mathrm{L}^{-1}$ in rainwater $(n=1), 150.1-705.79 \mathrm{mg} \mathrm{L}^{-1}$ (average: $370.68 \mathrm{mg} \mathrm{L}^{-1}$ ) in surface water $\left(n=3\right.$ ), and $47.22-152.78 \mathrm{mg} \mathrm{L}^{-1}$ (average: $\left.90.61 \mathrm{mg} \mathrm{L}^{-1}\right)$ in groundwater $(n=6)$. In comparison with the adjacent Shuicheng and Nandong subterranean river basins, $\mathrm{SO}_{4}{ }^{2-}$ is enriched more significantly in the precipitation, surface water, and groundwater samples in the BSRB. 

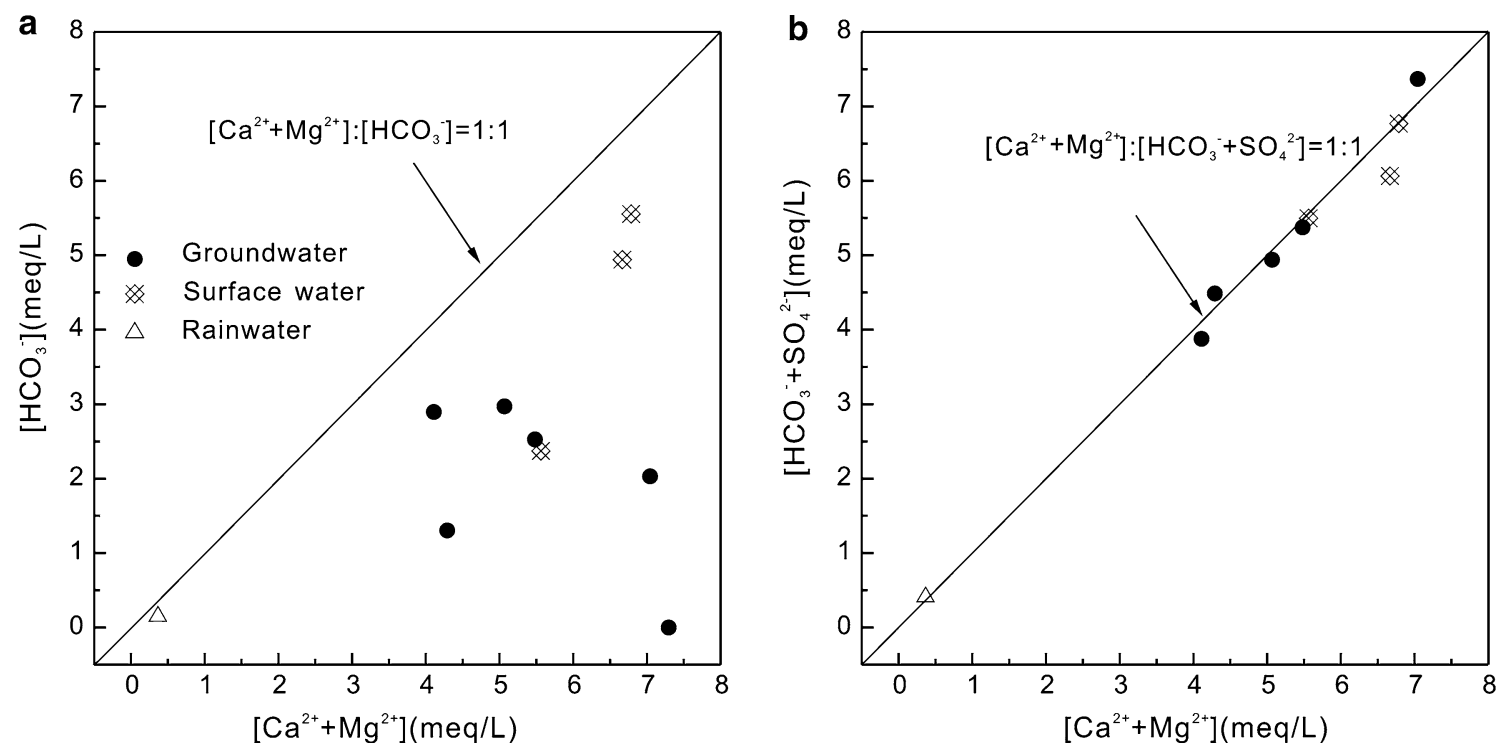

Fig. 4 Relationship between $\left[\mathrm{Ca}^{2+}+\mathrm{Mg}^{2+}\right]$ and $\left[\mathrm{HCO}_{3}{ }^{-}\right]$(a) and $\left[\mathrm{HCO}_{3}{ }^{-}+\mathrm{SO}_{4}{ }^{2-}\right]$ (b) in rainwater, surface water, and groundwater in the BSRB

Figure 5 shows the concentrations of $\mathrm{SO}_{4}{ }^{2-}$ in rainwater, surface water, and groundwater in the BSRB. Overall, the order of $\mathrm{SO}_{4}{ }^{2-}$ concentration in the different samples is surface water $>$ groundwater $>$ rainwater. In the BSRB, farmers use coal as their primary energy source and they usually stockpile the coal outside their houses (Fig. 6a), whereas low-grade coal is generally stored arbitrarily at coal mines (Fig. 6b, c). In addition, the rainy season is usually characterized by heavy precipitation in this area. Consequently, coal leachates and water from abandoned coal mines (Fig. 6d) flow directly into the surface rivers, leading to high $\mathrm{SO}_{4}{ }^{2-}$ concentrations in the surface water.

Although the karst aquifer hinders the removal of $\mathrm{SO}_{4}{ }^{2-}$ in groundwater [33], it can adsorb $\mathrm{SO}_{4}{ }^{2-}$ to some extent [34]. In this study, the $\mathrm{SO}_{4}{ }^{2-}$ concentrations of the two gravity-fed spring samples (GW02 and GW03),

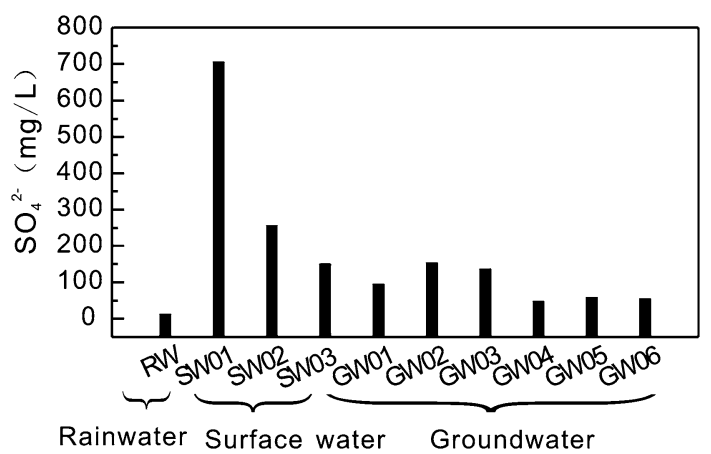

Fig. $5 \mathrm{SO}_{4}{ }^{2-}$ concentrations of precipitation, surface water, and groundwater in the BSRB which are located in the same water-conducting fracture zone (Fig. 1, GW02 is above the water flow of GW03), decrease by approximately $10.5 \%$ from $152.78 \mathrm{mg} \mathrm{L}^{-1}$ in GW02 to $136.72 \mathrm{mg} \mathrm{L}^{-1}$ in GW03 (Table 1). This is consistent with the findings by Guo et al. [34] and it indicates that $\mathrm{SO}_{4}{ }^{2-}$ concentrations could decrease, even when runoff water infiltrates directly into the karst aquifer through sinkholes, karst windows, and karst fissures. In addition, the subterranean river might have a certain dilution effect. Therefore, the $\mathrm{SO}_{4}{ }^{2-}$ concentration in groundwater is lower than in surface water. Precipitation is formed mainly from evaporated moisture that has relatively few impurities such as dissolved $\mathrm{SO}_{2}$ and sulfur-containing aerosols. Accordingly, the $\mathrm{SO}_{4}{ }^{2-}$ concentration of rainwater is lower than surface water and groundwater. The $\left[\mathrm{SO}_{4}{ }^{2-}\right]:\left[\mathrm{HCO}_{3}{ }^{-}\right]$ratio in the water of the BSRB is consistent with that in Guiyang City [35], indicating high diversity of $\mathrm{SO}_{4}{ }^{2-}$ sources in the researched region.

\section{Sources of $\mathrm{SO}_{4}^{2-}$}

Potential sources of $\mathrm{SO}_{4}{ }^{2-}$ in surface water and groundwater

Because of excessive mining and consumption of coal in Guizhou Province, Guizhou has become one of the provinces in southern China most affected by sulfuric acid rain [36]. Atmospheric precipitation, which is the main source for replenishing both surface water and groundwater in the BSRB, has a concentration of $\mathrm{SO}_{4}{ }^{2-}$ as high as 

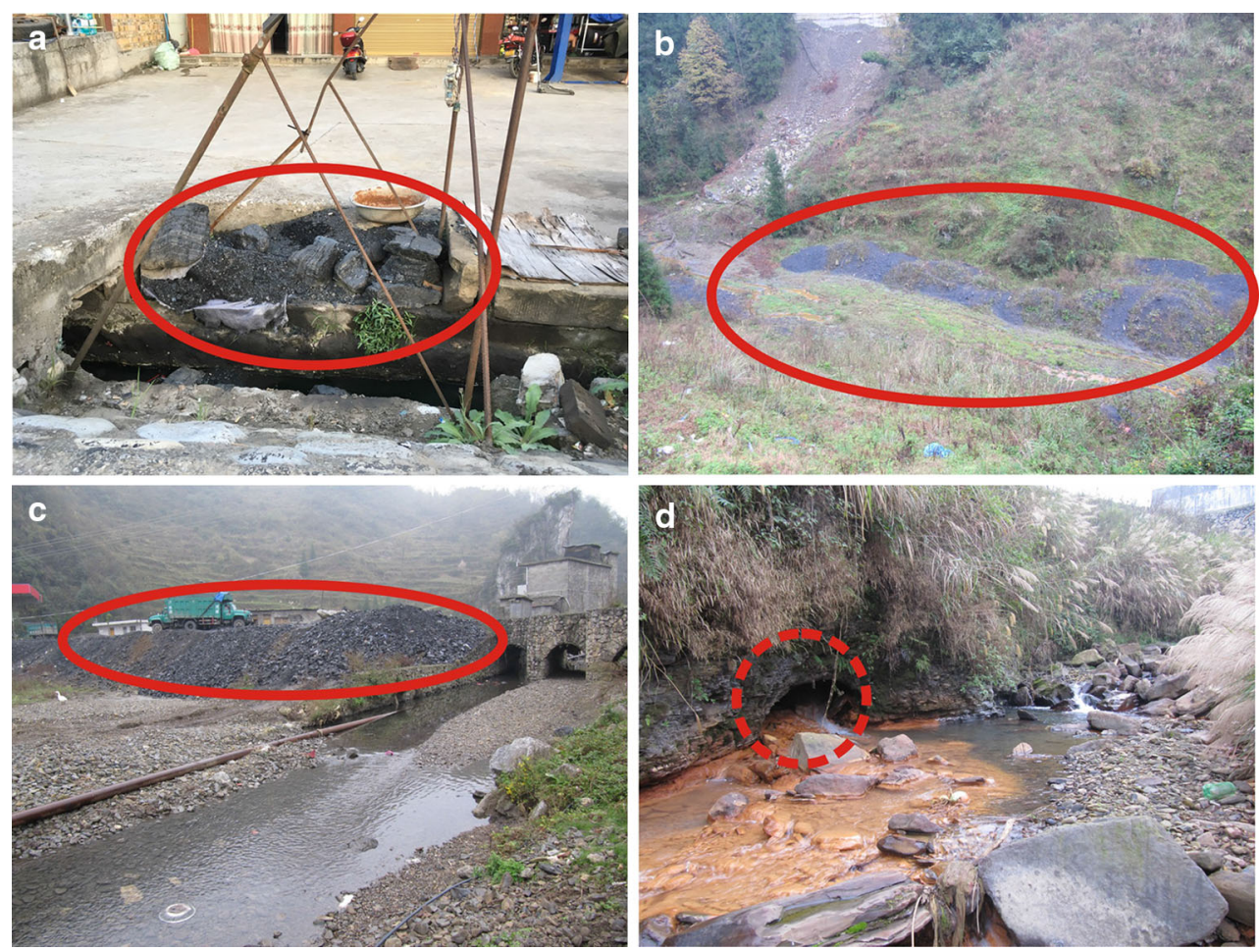

Fig. 6 Coal stockpiled outside a farmer's houses (a), low-grade coal stored in a karst depression (b), low-grade coal stored near a surface river (c), and water from an abandoned coal mine in the BSRB (d)

$12.36 \mathrm{mg} \mathrm{L}^{-1}$. Therefore, precipitation is an important source of $\mathrm{SO}_{4}{ }^{2-}$ in both surface water and groundwater in this area. Figure 2 shows there are rich coal seams between the $\mathrm{P}_{2} l, \mathrm{P}_{2} c$, and $\mathrm{P}_{2} d$ strata in the BSRB, while the $\mathrm{T}_{2} g^{1}$ stratum contains gypsum. The oxidation of sulfides in coal seams and the dissolution of gypsum would increase the concentration of $\mathrm{SO}_{4}{ }^{2-}$ in both surface water and groundwater $[2,17,37]$. The two reactions can be written as follows:

$$
\begin{aligned}
& \mathrm{FeS}_{2}+15 / 4 \mathrm{O}_{2}+7 / 2 \mathrm{H}_{2} \mathrm{O}=\mathrm{Fe}(\mathrm{OH})_{3}+2 \mathrm{SO}_{4}{ }^{2-} \\
& +4 \mathrm{H}^{+} \text {, } \\
& \mathrm{CaSO}_{4}=\mathrm{Ca}^{2+}+\mathrm{SO}_{4}{ }^{2-} \text {. }
\end{aligned}
$$

Jiang [38] found that sulfate contents in the yellow soil and lime soil of the Wujiang River Basin were very low, and that only very small amounts of $\mathrm{SO}_{4}{ }^{2-}$ enter the surface water and groundwater from these soils. This area has a very fragile ecological environment with relatively little human activity and limited use of agricultural chemical fertilizers. Hence, the amount of $\mathrm{SO}_{4}{ }^{2-}$ introduced by fertilizers, domestic sewage, and industrial wastewater is negligible. Therefore, the potential $\mathrm{SO}_{4}{ }^{2-}$ sources for surface water and groundwater in the BSRB, which has a comparable environment and level of human activities, are mainly precipitation, oxidation of sulfides in coal seams, and gypsum dissolution.
Source identification of $\mathrm{SO}_{4}{ }^{2-}$ in surface water and groundwater

The $\delta^{34} \mathrm{~S}_{\mathrm{SO}_{4}}$ signature of atmospheric precipitation is not correlated with the $\mathrm{SO}_{4}{ }^{2-}$ concentration or the amount of precipitation, but it is related only to pollution sources [39]. The $\delta^{34} \mathrm{~S}_{\mathrm{SO}_{4}}$ value of precipitation differs significantly between northern and southern China. In areas south of the Yangtze River, a larger amount of isotopically lighter sulfur is present in precipitation, resulting in negative $\delta^{34} \mathrm{~S}_{\mathrm{SO}_{4}}$ values, whereas in areas to the north, mainly isotopically heavier sulfur is present, resulting in positive $\delta^{34} \mathrm{~S}_{\mathrm{SO}_{4}}$ values [40]. The $\delta^{34} \mathrm{~S}_{\mathrm{SO}_{4}}$ value in precipitation during summer in Guiyang City varies between -8.1 and $-4.9 \%$ [ 40,41$]$. Currently, in the Yangtze River Basin area, $\delta^{18} \mathrm{O}_{\mathrm{SO}_{4}}$ values in precipitation have been reported only for Wuhan City, which range between +8 and $+15 \%$ o [42]. Therefore, ranges of -8.1 to $-4.9 \%$ and +8 to $+15 \%$ were used as the $\delta^{34} \mathrm{~S}_{\mathrm{SO}_{4}}$ and $\delta^{18} \mathrm{O}_{\mathrm{SO}_{4}}$ eigenvalues, respectively, to determine the fraction of $\mathrm{SO}_{4}{ }^{2-}$ that originates from atmospheric precipitation in this study.

Guizhou is a multi-age coal area. The upper Permian coal-bearing stratum contains the largest amount of coal and thus, it has become the main coal seam for mining because of its multiple advantages such as large reserves, shallow burial depth, and good exploration conditions. 
Guizhou coal is characterized by high sulfur content and a low $\delta^{34} \mathrm{~S}_{\mathrm{SO}_{4}}$ value. It is a typical high-sulfur-content coal, as evidenced by sulfur contents ranging between 3.12 and 9.08\% (average: $5.5 \%$ ). The $\delta^{34} \mathrm{~S}_{\mathrm{SO}_{4}}$ values vary between -15 and $-2.51 \%$, with an average value of $-7.52 \%$ o $[38,40]$. The $\delta^{18} \mathrm{O}_{\mathrm{SO}_{4}}$ signature resulting from oxidation of sulfides in the coal seams depends on the source of the oxygen for oxidation [43], and the $\delta^{18} \mathrm{O}_{\mathrm{SO}_{4}}$ values of Guizhou coal vary between -5 and $+4 \%$ [14]. Therefore, ranges of -15 to $-2.51 \%$ and -5 to $+4 \%$ were used as the $\delta^{34} \mathrm{~S}_{\mathrm{SO}_{4}}$ and $\delta^{18} \mathrm{O}_{\mathrm{SO}_{4}}$ eigenvalues, respectively, to determine the fraction of $\mathrm{SO}_{4}{ }^{2-}$ that originates from oxidized sulfides in the coal seams.

The gypsum in the Cambrian gypsolytes has the highest $\delta^{34} \mathrm{~S}_{\mathrm{SO}_{4}}$ values of up to $+32 \%$. The gypsum in the Permian and Triassic gypsolytes has relatively lower $\delta^{34} \mathrm{~S}_{\mathrm{SO}_{4}}$ values, ranging between $+10 \%$ and $+28 \%$ [44], which is still higher than the values of the precipitation and the sulfides in the coal seams. The $\delta^{18} \mathrm{O}_{\mathrm{SO}_{4}}$ values of gypsum are also high, ranging between +14.5 and $+32.5 \%$ o $[15,16]$. The BSRB consists mainly of Permian and Triassic strata, but it does not contain Cambrian strata. Therefore, ranges of +10 to $+28 \%$ and +14.5 to $+32.5 \%$ o were used as the $\delta^{34} \mathrm{~S}_{\mathrm{SO}_{4}}$ and $\delta^{18} \mathrm{O}_{\mathrm{SO}_{4}}$ eigenvalues, respectively, to identify $\mathrm{SO}_{4}{ }^{2-}$ that originates from gypsum dissolution.

According to the relationship of $\delta^{34} \mathrm{~S}_{\mathrm{SO}_{4}}$ and $1 /\left[\mathrm{SO}_{4}{ }^{2-}\right]$ shown in Fig. 7, it is clear that the $\delta^{34} \mathrm{~S}_{\mathrm{SO}_{4}}$ value of GW05 points toward dissolved gypsum as the $\mathrm{SO}_{4}{ }^{2-}$ source, and that samples SW01, SW03, GW02, and GW03 indicate sulfide oxidation in coal seams as the $\mathrm{SO}_{4}{ }^{2-}$ source. Because of the overlap of the $\delta^{34} \mathrm{~S}_{\mathrm{SO}_{4}}$ values in precipitation and oxidized sulfides, $\mathrm{SO}_{4}{ }^{2-}$ sources for samples SW02, GW04, and GW06 cannot be identified accurately. In addition, the $\delta^{34} \mathrm{~S}_{\mathrm{SO}_{4}}$ value of GW01 is different from the isotope ranges of all three potential sulfur sources. Sample GW05 was collected from a gravity-fed spring that outcrops in the $\mathrm{T}_{2} g^{1}$ stratum (Fig. 1). Because this stratum contains gypsum (Fig. 2), the dissolution of gypsum is the main source of $\mathrm{SO}_{4}{ }^{2-}$ in GW05. Sample SW01 is pit water from an abandoned coal mine and it has a low $\mathrm{pH}$ value of $2.70, \mathrm{SO}_{4}{ }^{2-}$ concentration of $705.79 \mathrm{mg} \mathrm{L}^{-1}$, and $\delta^{34} \mathrm{~S}_{\mathrm{SO}_{4}}$ value of $-12.95 \%$. The $\delta^{34} \mathrm{~S}_{\mathrm{SO}_{4}}$ value of SW01 is close to the average value of $-13 \%(n=5)$ for coal mine wastewater in Guizhou, reported by Jiang et al. [38]. Sample SW03 is a water sample from a surface stream formed by water seeping through coal piles near residential areas (the distance between the sampling site and the coal pile is approximately $350 \mathrm{~m}$ ). The stream water dissolves the underlying carbonate rocks, causing the $\mathrm{pH}$ value of the water to increase to 7.69 . The $\delta^{34} \mathrm{~S}_{\mathrm{SO}_{4}}$ value of SW03 is

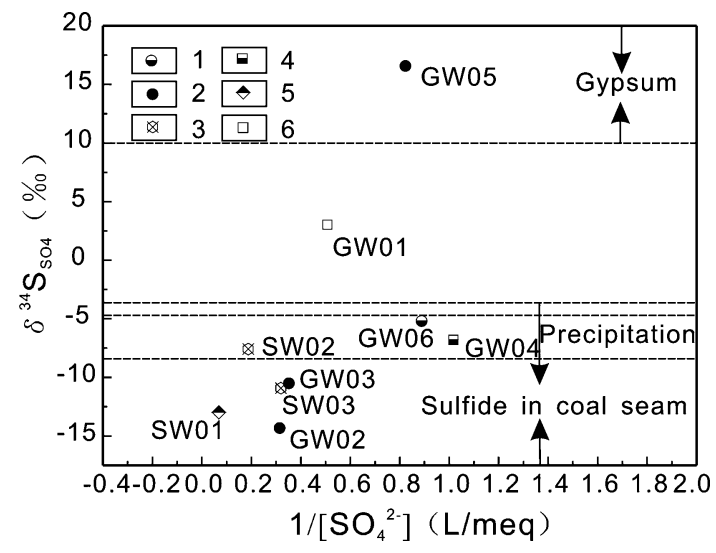

Fig. 7 Relationship between $\delta^{34} \mathrm{~S}_{\mathrm{SO}_{4}}$ and $1 /\left[\mathrm{SO}_{4}{ }^{2-}\right]$ for different water types in the BSRB: 1 Karst wells; 2 gravity-fed springs; 3 surface water; 4 water discharging from karst caves; 5 coal mine pit water; 6 exit of the subterranean river

still $-10.91 \%$, implying that the $\mathrm{SO}_{4}{ }^{2-}$ source might be oxidized sulfides from coal seams. Samples GW02 and GW03 are from two gravity-fed springs, both of which outcrop in the $\mathrm{T}_{1} y$ stratum (Fig. 2, this stratum does not contain coal seams) and are located in the same waterconducting fracture zone (Fig. 1). Groundwater from coalrich zones flows to the sites of GW02 and GW03 and then emerges on the surface, with $\delta^{34} \mathrm{~S}_{\mathrm{SO}_{4}}$ values of -14.32 and $-10.49 \%$, respectively, indicating that $\mathrm{SO}_{4}{ }^{2-}$ originates from oxidized sulfides. Sample GW01 is water from the exit of the Babu subterranean river. Precipitation enters the subterranean river through sinkholes, karst windows, or by infiltration through the soil layer. During infiltration, the water passes through layers containing coal or gypsum and consequently, the $\mathrm{SO}_{4}{ }^{2-}$ in the subterranean river originates from different sources. By analyzing the $\delta^{34} \mathrm{~S}_{\mathrm{SO}_{4}}$ composition of the water samples, we accurately identified that the source of $\mathrm{SO}_{4}{ }^{2-}$ in GW05 is mainly gypsum, and that the $\mathrm{SO}_{4}{ }^{2-}$ in samples SW01, SW03, GW02, and GW03, is derived from coal seams containing sulfides. However, GW01 has mixed $\mathrm{SO}_{4}{ }^{2-}$ sources, namely precipitation, oxidation of sulfides in coal seams, and gypsum dissolution.

For sampling sites SW02, GW04, and GW06, $\delta^{34} \mathrm{~S}_{\mathrm{SO}_{4}}$ analysis alone is insufficient for source identification of $\mathrm{SO}_{4}{ }^{2-}$ because of the overlapping $\delta^{34} \mathrm{~S}_{\mathrm{SO}_{4}}$ ranges of precipitation and sulfides in coal seams; therefore, $\delta^{34} \mathrm{~S}_{\mathrm{SO}_{4}}$ and $\delta^{18} \mathrm{O}_{\mathrm{SO}_{4}}$ need to be used jointly (Fig. 8). The site of SW02 is a small surface creek fed by precipitation, and the sampled water does not flow through coal seams or gypsum-containing strata (Fig. 1). Consequently, the $\delta^{18} \mathrm{O}_{\mathrm{SO}_{4}}$ value of sample SW02 is $+9.13 \%$, which is within the eigenvalue range for $\mathrm{SO}_{4}{ }^{2-}$ of precipitation origin, i.e., between +8 and $+15 \%$, suggesting that the main source of 
$\mathrm{SO}_{4}{ }^{2-}$ in SW02 is precipitation. The sampling site of GW04 is a water-discharging karst cave where water flows at a rate of $7.5 \mathrm{~L} \mathrm{~s}^{-1}$. Because of the wide potential source area, the water at site GW04 might come from coal seams or gypsum-bearing strata, leading to a $\delta^{18} \mathrm{O}_{\mathrm{SO}_{4}}$ value representing multiple $\mathrm{SO}_{4}{ }^{2-}$ sources. Sample GW06 is karst well water, which represents the maximum burial depth of the underground water. Its $\delta^{18} \mathrm{O}_{\mathrm{SO}_{4}}$ value falls within the range representing oxidized sulfides in coal seams as the source of $\mathrm{SO}_{4}{ }^{2-}$.

In summary, the main source of $\mathrm{SO}_{4}{ }^{2-}$ in surface water sample SW02 from the BSRB is precipitation. The main $\mathrm{SO}_{4}{ }^{2-}$ source for surface water samples SW01 and SW03 and underground water samples GW02, GW03, and GW06 is sulfide in coal seams. The main source of $\mathrm{SO}_{4}{ }^{2-}$ in GW05 is gypsum, while GW01 and GW04 have mixed $\mathrm{SO}_{4}{ }^{2-}$ sources.

\section{Contribution of different $\mathrm{SO}_{4}{ }^{2-}$ sources to the karst water system}

The flux at the exit of the subterranean river represents the total water flow of the karst water system and it can provide information about the temporal and spatial distributions of water sources as well as the surface and underground water passages [45]. Therefore, the exit of the river is an important monitoring location for karst water. As discussed in the preceding section, the $\mathrm{SO}_{4}{ }^{2-}$ in the water at the exit of the Babu subterranean river originates from precipitation, coal seams, and gypsum. Therefore, the relative contributions of the three sources can be calculated based on the $\delta^{34} \mathrm{~S}_{\mathrm{SO}_{4}}$ value of the water at the main outlet (GW01) using the formula below:

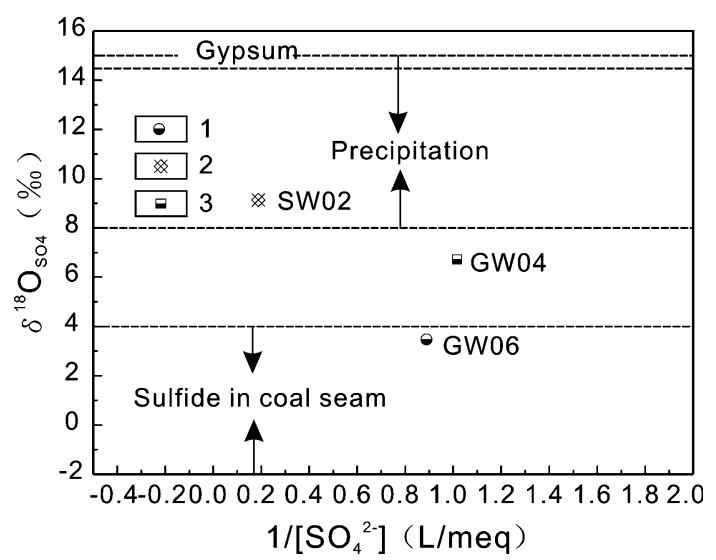

Fig. 8 Relationship between $\delta^{18} \mathrm{O}_{\mathrm{SO}_{4}}$ and $1 /\left[\mathrm{SO}_{4}{ }^{2-}\right]$ in different water types in the BSRB; 1 Karst wells; 2 surface water; 3 waterdischarging karst cave $\delta^{34} \mathrm{~S}_{\mathrm{SO}_{4}^{-G W 01}}=x \delta^{34} \mathrm{~S}_{\mathrm{SO}_{4}^{- \text {coal }}}+(1-x-y) \delta^{34} \mathrm{~S}_{\mathrm{SO}_{4}^{- \text {gyp }}}$

where $x(\%)$ is the percentage of $\mathrm{SO}_{4}{ }^{2-}$ from precipitation, $y(\%)$ is the percentage of $\mathrm{SO}_{4}{ }^{2-}$ from coal seams, $(1-x-y)(\%)$ is the percentage of $\mathrm{SO}_{4}{ }^{2-}$ from gypsum dissolution, $\delta^{34} \mathrm{~S}_{\mathrm{SO}_{4}^{-G W 01}}(\%)$ is the $\delta^{34} \mathrm{~S}_{\mathrm{SO}_{4}}$ value of the water at the exit of the subterranean river, $\delta^{34} \mathrm{~S}_{\mathrm{SO}_{4}^{-r a i n}}(\%)$ is the $\delta^{34} \mathrm{~S}_{\mathrm{SO}_{4}}$ value of the precipitation in the river basin, $\delta^{34} \mathrm{~S}_{\mathrm{SO}_{4}^{- \text {coal }}}(\%)$ is the $\delta^{34} \mathrm{~S}_{\mathrm{SO}_{4}}$ value of the water sample representing oxidized sulfides in coal seams, and $\delta^{34} \mathrm{~S}_{\mathrm{SO}_{4}^{- \text {gyp }}}$ (\%o) is the $\delta^{34} \mathrm{~S}_{\mathrm{SO}_{4}}$ value of the water sample representing dissolssved gypsum in the river basin. In accordance with the mass conservation law, the contribution of precipitation is calculated to be $13 \%$. In the calculations, an average $\delta^{34} \mathrm{~S}_{\mathrm{SO}_{4}}$ value of $-7 \%$ o for summer precipitation in Guiyang City is used as the $\delta^{34} \mathrm{~S}_{\mathrm{SO}_{4}}$ precipitation value [40]. The average $\delta^{34} \mathrm{~S}_{\mathrm{SO}_{4}}$ value of SW01, SW03, GW02, GW03, and GW06 is used to represent the oxidized sulfides in the coal seams as the $\mathrm{SO}_{4}{ }^{2-}$ source. The $\delta^{34} \mathrm{~S}_{\mathrm{SO}_{4}}$ value of sample GW05 is used to represent dissolved gypsum as the $\mathrm{SO}_{4}{ }^{2-}$ source. The calculation yields the contributions from sulfide oxidation in coal seams and gypsum dissolution are 40 and $47 \%$, respectively. It is acknowledged that the calculation result might be affected by the small number of precipitation and surface water samples. However, the finding that the contribution from oxidized sulfides in coal seams is smaller than the contribution from gypsum dissolution is in accordance with the observation that coal seams (approximately $6.2 \%$ of the total area) occupy a smaller part of the study area than the gypsum-containing strata (approximately $17.1 \%$ of the total area).

The contribution of $\mathrm{SO}_{4}{ }^{2-}$ from precipitation to the Babu subterranean river water derived in this study is slightly smaller than that reported by both Li et al. [1] and Zhang et al. [12] for the Jialing and Yellow River areas, respectively. This might be attributable to a buffering effect during precipitation infiltration into the subterranean river or to chemical changes of the water flowing through the coal seams and gypsum strata. However, the $\mathrm{SO}_{4}{ }^{2-}$ contribution from precipitation to the subterranean river outflow reaches $13 \%$, demonstrating that the adverse effect on underground water quality by acidic rain resulting from the consumption of coal by human activities cannot be overlooked. The open storage of coal also contributes to the large contribution of $\mathrm{SO}_{4}{ }^{2-}(40 \%)$ from sulfide oxidation in coal seams. Therefore, it is necessary to require local residents and coal mining companies to ensure coal is stored appropriately. 


\section{Conclusions}

In the BSRB area, the main source for surface water and groundwater is precipitation, and the main source of $\mathrm{Ca}^{2+}, \mathrm{Mg}^{2+}$, and $\mathrm{HCO}_{3}{ }^{-}$in these waters is the dissolution of carbonate rocks. Together with carbonic acid, sulfuric acid contributes to the dissolution of carbonate rocks and $\mathrm{Ca}^{2+} / \mathrm{Mg}^{2+}$-containing particles produced by cement industries. In the study area, the concentration of $\mathrm{SO}_{4}{ }^{2-}$ in rainwater is $12.36,150.1-705.79 \mathrm{mg} \mathrm{L}^{-1}$ (average: $70.68 \mathrm{mg} \mathrm{L}^{-1}$ ) in surface water, and $47.22-$ $152.78 \mathrm{mg} \mathrm{L}^{-1}$ (average: $90.61 \mathrm{mg} \mathrm{L}^{-1}$ ) in groundwater. Accordingly, the order of $\mathrm{SO}_{4}{ }^{2-}$ concentration in the different samples is surface water $>$ groundwater $>$ rainwater. Compared with adjacent regions, the rainwater, surface water, and groundwater show $\mathrm{SO}_{4}{ }^{2-}$ enrichment in the BSRB. The $\delta^{34} \mathrm{~S}_{\mathrm{SO}_{4}}$ and $\delta^{18} \mathrm{O}_{\mathrm{SO}_{4}}$ values in the surface water samples range between -12.98 and $-10.19 \%$, and between -0.54 and $+9.13 \%$, respectively. The main sources of $\mathrm{SO}_{4}{ }^{2-}$ are precipitation for $\mathrm{SW02}$ and sulfide oxidation in coal seams for SW01 and SW03. The $\delta^{34} \mathrm{~S}_{\mathrm{SO}_{4}}$ and $\delta^{18} \mathrm{O}_{\mathrm{SO}_{4}}$ values of the groundwater samples range between -14.32 and $+16.58 \%$ and between +2.81 and $+14.35 \%$, respectively. The main sources of $\mathrm{SO}_{4}{ }^{2-}$ are sulfide oxidation in coal seams for GW02, GW03, and GW06, and gypsum dissolution for GW05. At sampling sites GW01 and GW04, $\mathrm{SO}_{4}{ }^{2-}$ originates from mixed sources. The $\mathrm{SO}_{4}{ }^{2-}$ contribution of precipitation to the water at the exit of the Babu subterranean river is 13\%; sulfide oxidation in coal seams contributes $40 \%$, and gypsum dissolution contributes $47 \%$. The mining, open storage, and consumption of coal have all exerted significant adverse impacts on the water quality of the Babu subterranean river that should not be overlooked. The BSRB and the entire province should develop a sustainable strategy for the exploration and use of coal in order to balance the needs of economic development and water quality protection.

Acknowledgements This work was supported by the National Natural Science Foundation of China [Grant No. 41103068], China Geological Survey Project [Grant No. DD201180285], and Special Items of Basic Scientific Research projects of the Chinese Academy of Geological Sciences [Grant No. 2016005]. We are grateful to Ganjiang Lan and Xiaojun Meng for their generous help during fieldwork. In addition, we offer special thanks to the reviewers and editors who provided us with valuable suggestions.

Open Access This article is distributed under the terms of the Creative Commons Attribution 4.0 International License (http://crea tivecommons.org/licenses/by/4.0/), which permits unrestricted use, distribution, and reproduction in any medium, provided you give appropriate credit to the original author(s) and the source, provide a link to the Creative Commons license, and indicate if changes were made.

\section{References}

1. Li XD, Liu CQ, Liu XL, Bao LR (2011) Identification of dissolved sulfate sources and the role of sulfuric acid in carbonate weathering using dual-isotopic data from the Jialing River, Southwest China. J Asian Earth Sci 42(3):370-380

2. Marques JM, Graça H, Eggenkamp HGM, Neves O, Carreira PM, Matias MJ, Mayer B, Nunes D, Trancoso VN (2013) Isotopic and hydrochemical data as indicators of recharge areas, flow paths and water-rock interaction in the Caldas da Rainha-Quinta das Janelas thermomineral carbonate rock aquifer (Central Portugal). J Hydrol 476(18):302-313

3. Tostevin R, Turchyn AV (2014) Multiple sulfur isotope constraints on the modern sulfur cycle. Earth Planet Sci Lett 396:14-21

4. Liu CQ, Lang YC, Satake H, Wu J, Li SL (2008) Identification of anthropogenic and natural inputs of sulfate and chloride into the karstic ground eater of Guiyang, SW China: combined $\delta^{37} \mathrm{Cl}$ and $\delta^{34} \mathrm{~S}$ approach. Environ Sci Technol 42(15):5421-5427

5. Jiang Y, Wu YX, Yuan DX (2009) Human impacts on karst groundwater contamination deduced by coupled nitrogen with strontium isotopes in the Nandong Underground River System in Yunan, China. Environ Sci Technol 43(20):7676-7683

6. Crowley SF, Mccarthy MDB, Bottrell SH, Ward J, Young B (1997) \& \#x03B4;34S of lower carboniferous anhydrite, cumbria and its implications for Barite Mineralization in the Northern Pennines. J Geol Soc Lond 154(4):597-600

7. Hosono T, Nakano T, Igeta A, Tayasu I, Tanaka T, Yachi S (2007) Impact of fertilizer on a small watershed of lake biwa: use of sulfur and strontium isotopes in environmental diagnosis. Sci Total Environ 384(1-3):342-354

8. Hosono T, Ikawa R, Shimada J, Nakano T, Saito M, Onodera SI, Lee KK, Taniguchi M (2009) Human impacts on groundwater flow and contamination deduced by multiple isotopes in Seoul City, South Korea. Sci Total Environ 407(9):3189-3197

9. Li XD, Liu CQ, Harue M, Li SL, Liu XL (2010) The use of environmental isotopic $(\mathrm{C}, \mathrm{Sr}, \mathrm{S})$ and hydrochemical tracers to characterize anthropogenic effects on karst groundwater quality: a case study of the Shuicheng Basin, SW China. Appl Geochem 25(12):1924-1936

10. Carucci V, Petitta M, Aravena R (2012) Interaction between shallow and deep aquifers in the Tivoli Plain (Central Italy) enhanced by groundwater extraction: a multi-isotope approach and geochemical modeling. Appl Geochem 27(1):266-280

11. Hosono T, Siringan F, Yamanaka T, Yu U, Onodera SI, Nakano T, Taniguchi M (2010) Application of multi-isotope ratios to study the source and quality of urban groundwater in Metro Manila, Philippines. Appl Geochem 25(6):900-909

12. Zhang D, Huang XY, Li CJ (2013) Sources of riverine in Yellow river and its tributaries determined by sulfur and oxygen isotopes. Adv Water 24(3):418-426. doi:10.14042/j.cnki.32.1309.2013.03. 021 (in Chinese with English abstract)

13. Mayer B, Shanley JB, Bailey SW, Mitchell MJ (2010) Identifying sources of stream water sulfate after a summer drought in the Sleepers River watershed (Vermont, USA) using hydrological, chemical, and isotopic techniques. Appl Geochem 25(5):747-754

14. Krouse HR, Mayer B (2000) Sulphur and oxygen isotopes in sulphate. In: Cook PG, Herczeg AL (eds) Environmental tracers in subsurface hydrology. Kluwer Academic Press, Boston

15. Goldberg T, Poulton SW, Strauss H (2005) Sulphur and oxygen isotope signatures of late Neoproterozoic to early Cambrian sulphate, Yangtze Platform, China: diagenetic constraints and seawater evolution. Precambrian Res 137(3-4):223-241

16. Strauss H (1997) The isotopic composition of sedimentary sulfur through time. Palaeogeogr Palaeocl 132(1-4):97-118 
17. Al-Charideh A (2015) Isotopic evidence to characterize the sources of sulfate ions in the carbonate aquifer system in Aleppo basin (North Syria). Environ Earth Sci 73(1):127-137

18. Ford D, Williams P (2007) Karst hydrogelology and geomorphology. Wiley, New York

19. Vesper DJ, White WB (2004) Spring and conduit sediments as storage reservoirs for heavy metals in karst aquifers. Environ Geol 45(4):481-493

20. Pu T, He Y, Zhang T, Wu J, Zhu G, Chang L (2013) Isotopic and geochemical evolution of ground and river waters in a karst dominated geological setting: a case study from Lijiang basin, South-Asia monsoon region. Appl Geochem 33:199-212

21. Al-Charideh A, Kattaa B (2016) Isotope hydrology of deep groundwater in Syria: renewable and non-renewable groundwater and paleoclimate impact. Hydrogeol J 24(1):79-98

22. Sidle WC (1998) Environmental isotopes for resolution of hydrology problems. Environ Monit Assess 52(3):389-410

23. Long AJ, Sawyer JF, Putnam LD (2008) Environmental tracers as indicators of karst conduits in groundwater in South Dakota, USA. Hydrogeol J 16(2):263-280

24. Zhai Y, Wang J, Huan H, Zhou J, Wei W (2013) Characterizing the groundwater renewability and evolution of the strongly exploited aquifers of the North China Plain by major ions and environmental tracers. J Radioanal Nucl Chem 296(3):1263-1274

25. Zhai Y, Wang J, Zhang BT, Guo Y, Teng Y, Zhou J (2014) Physical, hydrochemical and isotopic characteristics of springs in Beijing, China, compared to historical properties. J Radioanal Nucl Chem 300(1):315-323

26. Yu D, Tang C, Shen Y (2014) Identifying interactions between river water and groundwater in the North China Plain using multiple tracers. Environ Earth Sci 72(1):99-110

27. Craig H (1961) Isotopic variations in meteoric waters. Science 133(3465):1702-1703

28. Zhao JF, Xia KQ, Shi YC, Sun JY (2004) Isotope component characteristics of groundwater of Geleshan Tunnal' Chongqing. Chin J Geol Hazard Control 15(2):94-97. doi:10.16031/j.cnki. issn.1003-8035.2004.02.020 (in Chinese with English abstract)

29. Yang PH, Lu BQ, He QF, Chen XB (2014) Hydrogeochemical characteristics of typical karst groundwater system in Chongqing. Environ Sci 35(4):1290-1296. doi:10.13227/j.hjkx.2014.04.012 (in Chinese with English abstract)

30. Barnes RT, Raymond PA (2009) The contribution of agricultural and urban activities to inorganic carbon fluxes within temperate watersheds. Chem Geo. 266(3-4):318-327

31. Han G, Liu CQ (2006) Strontium isotope and major ion chemistry of the rainwaters from Guiyang, Guizhou Province, China. Sci Total Environ. 364(1-3):165-174
32. Jiang Y (2012) Sources of sulfur in the Nandong underground river system, southwest China: a chemical and isotopic reconnaissance. Appl Geochem 27(8):1463-1470

33. Bottrell SH, Moncaster SJ, Tellam JH, Lloyd JW, Fisher QJ, Newton RJ (2000) Controls on bacterial sulphate reduction in a dual porosity aquifer system: the Lincolnshire Limestone aquifer, England. Chem Geol 169(3-4):461-470

34. Guo F, Wang WK, Jiang GH, Ma ZJ (2014) Contaminant transport behavior in a karst subterranean river and its capacity of self-purification: a case study of Lihu, Guangxi. Adv Water Sci 25(3):414-419. doi:10.14042/j.cnki.32.1309.2014.03.017 (in Chinese with English abstract)

35. Lang YC, Liu CQ, Zhao ZQ, Li SL, Han GL (2006) Geochemistry of surface and ground water in Guiyang, China: water/rock interaction and pollution in a karst hydrological system. Appl Geochem 21(6):887-903

36. Han G, Tang Y, Xu Z (2010) Fluvial geochemistry of rivers draining karst terrain in Southwest China. J Asian Earth Sci 38(1):65-75

37. Krajkó J, Varga Z, Wallenius M, Mayer K, Konings R (2016) Investigation of sulphur isotope variation due to different processes applied during uranium ore concentrate production. J Radioanal Nucl Chem 309(3):1-9

38. Jiang YK, Liu CQ, Tao FX (2006) The role of sulfur cycling in carbonate weathering: isotope geochemistry of sulfur in the Wujiang River catchment, Southwest China. Chin J Geochem 25(1):278

39. Wu Y, Xu ZF (2013) Progress in research on stable isotopes in precipitation in China: a review. Earth Environ 41(6):688-695. doi:10.14050/j.cnki.1672-9250.2013.06.012 (in Chinese with English abstract)

40. Hong YT, Zhang HB, Zhu YX (1993) Sulfur isotopic characteristics of coal in China and sulfur isotopic fractionation during coal-burning process. Chin J Geochem 12(1):51-59

41. Xiao HY, Liu CQ (2002) Sources of nitrogen and sulfur in wet deposition at Guiyang, southwest China. Atmos Environ 36(33):5121-5130

42. Li X, Bao H, Gan Y, Liu Y (2013) Multiple oxygen and sulfur isotope compositions of secondary atmospheric sulfate in a megacity in central China. Atmos Environ 81(4):591-599

43. Mango H, Ryan P (2015) Source of arsenic-bearing pyrite in southwestern Vermont, USA: sulfur isotope evidence. Sci Total Environ 505:1331-1339

44. Krouse HR, Crinenko VA (eds) (1991) Stable isotopes: natural and anthropogenic sulphur in the environment. Wiley, New York

45. Goldscheider N, Drew D (2007) Methods in karst hydrogeology. Taylor \& Francis, London 